\title{
Source Theory and the Philosophy of Religion
}

\section{WRS and MRS as systems}

We now consider the applicability of Source Theory and its basic concepts to other fields of philosophy. Since we deal with data and data processing in most spheres of life, it seems that we can apply Source Theory to a wide range of disciplines. For the present discussion, I will use only three examples, as stated in the introduction.

One of the most appropriate applications of Source Theory is in the philosophy of religion. We have already discussed the Western Rational System (WRS) and the Monotheist Religious System (MRS), presented in Chapter Four, as examples of two different cultural systems. These two systems can provide us with an excellent test case for applying Source Theory since each one represents an important, centuries-old tradition of thought, and they have considered each other as rivals for much of this time. We will therefore use them in this chapter as a concrete example of the application of Source Theory to the philosophy of religion.

For our purposes, WRS is the philosophical and scientific system that has been dominant in Western civilization at least since the nineteenth century, but its origins can be traced back to Greek philosophy. This system, in its mature form, evolved primarily in Christian cultures, and therefore still contains some religious remnants, but for our purposes we can consider these negligible, and see the entire system - at least as far as the ideal system is concerned - as secular. We have already called it $\mathrm{S}(\mathrm{m} 8)$.

The model of MRS that I will use here is roughly pertinent to Judaism, Christianity and Islam (or at least the more traditionalist and anti-modernist movements in these religions), with greater emphasis on Judaism. Indeed, it is likely to fit many of the non-monotheist religions as well, but since I cannot discuss

How to cite this book chapter:

Brown, B 2017 Thoughts and Ways of Thinking: Source Theory and Its Applications.

Pp. 73-102. London: Ubiquity Press. DOI: https://doi.org/10.5334/bbh.f. License:

CC-BY 4.0 
all of them here, I will confine myself to these three. These three traditions all accept the basic cognitive tools as truth sources, but add some testimonies: a text and its authorized interpreters. The adoption of the text and its authorized interpreters thus becomes a first principle of any religious tradition, and entails the belief in all its dogmas (See Sofer 1841-1912, Volume 2: 356). In this respect, even if the text and its interpreters vary from one tradition to another, they all share the same type of model, and in this sense we can treat them as one for our purposes. This is what justifies talking about MRS as one system, even though in reality there has never been a single unified system including all three monotheist religions. A discussion with higher "resolution" would therefore require a distinction between the three - MRS1, MRS2 and MRS3 - but for our discussion we will make do with MRS. We will denote its model as m7, and the system will therefore be denoted as $\mathrm{S}(\mathrm{m} 7)$.

My main interest in this chapter is in the conflict between the reason-based and the religious systems (in this context I use the term reason in its broader sense, as representing rationality, i.e., the source model founded on the basic cognitive tools, and not the specific function mentioned in Chapter One). In its medieval version, this discord was known as the "reason-revelation conflict"; in its modern version, it has taken the form of the science-religion conflict; here we will consider both of them under the general title of the reason-religion conflict. When dealing with practical reason in particular, we may also call it the morality-religion conflict (with morality, in this context, referring to secular-humanist morality).

Indeed, even in antiquity there was tension between religion and philosophy, but it emerged sharply only during the Middle Ages, when it became one of the major topics of philosophy and religious rationalism. The main discord was in the descriptive realm, that is, on the issue of the conflict between the data about the world transmitted by the religious traditions and their canonical texts on the one hand, and the data transmitted by the basic cognitive tools on the other. One major question that occupied the medieval thinkers was whether the world is eternal or created. The religious traditions claimed that the world was created ex nihilo at a particular point in time, while the Aristotelian philosophers, who reigned in the field at that time, claimed that the world is eternal and has always been in existence. At present, the conflict centers around the question of creation versus evolution, as well as the issue of the age of the universe. The conflicts in the normative realm have become most intense in the modern age. Among these are the debates over euthanasia and abortion, as well as the status of women, members of other religions, and heretics.

MRS and WRS are two great, wide-ranging systems with rich histories and glorious traditions. They differ from each other on a list of fundamental issues, but they also represent different ways of thinking. This insight is not only based on a source-theoretical analysis, but also accords with our empirically-based intuitions. We can often sense that purely religious people (if they exist at all 
nowadays) "think differently" from purely rationalist people (if there have ever been any). Thus the root of the great differences between them is their sources or the division of labor among them.

Here I will survey various approaches that have been put forward for dealing with these conflicts, and formulate them in terms of Source Theory. The various approaches include the rejection of religion, the rejection of reason, the doublefaith theory with religious supremacy, the double-faith theory with rationalist supremacy, the separation theory with religious supremacy in the descriptive realm, the separation theory with religious supremacy in the normative realm ("orthopraxy"), and the double-truth theory (as distinguished from the "double-faith" theory).

All these approaches are largely "ideal types". In practice, people are more complex, with more contradictions and arbitrariness than the theoretical types. I will therefore change my method of presentation and cite a list of quotations from thinkers representing each of these approaches. These thinkers come from different periods and cultures, and each of them dealt differently with the reason-religion conflict. As we shall see, hardly any of these thinkers belongs purely to the type of theory he is supposed to represent, so I will allow myself to slightly simplify their ideas from time to time so as to sharpen them. At any rate, the discussion does not revolve around the views of the thinkers themselves, but rather the ideal types that we will delineate with their assistance, even if some modifications are required.

\section{The adoption of reason and the rejection of religion}

The rejection of religion has been the approach of radical secular thinkers of all ages These thinkers adopt only the basic cognitive tools in the WRS model. If we call a typical member of this group a1, we can therefore say that a1 X::m8, i.e. that a1 exclusively adopts m8. Typical representatives of this approach are Baron d'Holbach and Bertrand Russell, who asserted that religion is based mainly on fear, while science liberates us from it. D'Holbach wrote:

Savage and furious nations, perpetually at war, adore, under divers names, some God, conformable to their ideas, that is to say, cruel, carnivorous, selfish, blood-thirsty. We find, in all the religions, "a God of armies," a "jealous God," an "avenging God," a "destroying God," a God who is pleased with carnage, and whom his worshippers consider it a duty to serve. Lambs, bulls, children, men, and women, are sacrificed to him. Zealous servants of this barbarous God think themselves obliged even to offer up themselves as a sacrifice to him. Madmen may everywhere be seen, who, after meditating upon their terrible God, imagine that to please him they must inflict on themselves the most exquisite 
torments. The gloomy ideas formed of the deity, far from consoling them, have every where disquieted their minds, and prejudiced follies destructive to happiness.

How could the human mind progress, while tormented with frightful phantoms, and guided by men interested in perpetuating its ignorance and fears? Man has been forced to vegetate in his primitive stupidity: he has been taught stories about invisible powers upon whom his happiness was supposed to depend. Occupied solely by his fears, and by unintelligible reveries, he has always been at the mercy of priests, who have reserved to themselves the right of thinking for him, and of directing his actions. Thus, man has remained a slave without courage, fearing to reason, and unable to extricate himself from the labyrinth in which he has been wandering. He believes himself forced under the yoke of his gods, known to him only by the fabulous accounts given by his ministers, who, after binding each unhappy mortal in the chains of prejudice, remain his masters, or else abandon him defenceless to the absolute power of tyrants, no less terrible than the gods, of whom they are the representatives.

Oppressed by the double yoke of spiritual and temporal power, it has been impossible for the people to be happy. Religion became sacred, and men have had no other Morality, than what their legislators and priests brought from the unknown regions of heaven. The human mind, confused by theological opinions, ceased to know its own powers, mistrusted experience, feared truth and disdained reason, in order to follow authority. Man has been a mere machine in the hands of tyrants and priests. Always treated as a slave, man has contracted the vices of slavery.

Such are the true causes of the corruption of morals. Ignorance and servitude are calculated to make men wicked and unhappy. Knowledge, Reason, and Liberty can alone reform and make men happier. But every thing conspires to blind them, and to confirm their errors. Priests cheat them, tyrants corrupt and enslave them. Tyranny ever was, and ever will be, the true cause of man's depravity, and also of his calamities. Almost always fascinated by religious fiction, poor mortals turn not their eyes to the natural and obvious causes of their misery; but attribute their vices to the imperfection of their natures, and their unhappiness to the anger of the gods. They offer to heaven vows, sacrifices, and presents, to obtain the end of sufferings, which in reality are attributable only to the negligence, ignorance, and perversity of their guides, to the folly of their customs, and above all, to the general want of knowledge. Let men's minds be filled with true ideas; let their reason be cultivated; and there will be no need of opposing to the passions, such a feeble barrier, as the fear of gods (Holbach 1900, preface). 
Russell clearly follows the same idea, and points to science as a better source:

Religion is based, I think, primarily and mainly upon fear. It is partly the terror of the unknown and partly, as I have said, the wish to feel that you have a kind of elder brother who will stand by you in all your troubles and disputes. Fear is the basis of the whole thing - fear of the mysterious, fear of defeat, fear of death. Fear is the parent of cruelty, and therefore it is no wonder if cruelty and religion have gone hand in hand. It is because fear is at the basis of those two things. In this world we can now begin a little to understand things, and a little to master them by help of science, which has forced its way step by step against the Christian religion, against the churches, and against the opposition of all the old precepts. Science can help us to get over this craven fear in which mankind has lived for so many generations. Science can teach us, and I think our own hearts can teach us, no longer to look around for imaginary supports, no longer to invent allies in the sky, but rather to look to our own efforts here below to make this world a better place to live in, instead of the sort of place that the churches in all these centuries have made it (Russell 1967: 26).

The expected conclusion is that religion should be completely rejected in favor of science, based on the basic cognitive tools, which Russell calls "intelligence":

We want to stand upon our own feet and look fair and square at the world - its good facts, its bad facts, its beauties, and its ugliness; see the world as it is and be not afraid of it. Conquer the world by intelligence and not merely by being slavishly subdued by the terror that comes from it. The whole conception of God is a conception derived from the ancient Oriental despotisms. It is a conception quite unworthy of free men. When you hear people in church debasing themselves and saying that they are miserable sinners, and all the rest of it, it seems contemptible and not worthy of self-respecting human beings. We ought to stand up and look the world frankly in the face. We ought to make the best we can of the world, and if it is not so good as we wish, after all it will still be better than what these others have made of it in all these ages. A good world needs knowledge, kindliness, and courage; it does not need a regretful hankering after the past or a fettering of the free intelligence by the words uttered long ago by ignorant men. It needs a fearless outlook and a free intelligence. It needs hope for the future, not looking back all the time toward a past that is dead, which we trust will be far surpassed by the future that our intelligence can create (ibid.: 26-27). 
When Russell uses the word "intelligence", he is speaking about the basic cognitive tools. When he claims that intelligence is free, he means that it should apprehend the world directly, without the mediation of any sort of accepted texts. When he says that "we want to stand upon our own feet", he means that we are not interested in any sort of intermediaries to whose authority we are subjected. All this implies the absolute rejection of traditional religion in favor of "intelligence" as a source of directly apprehending the world.

Later versions of atheism flourished in the 20th century and the list is too long for even a short survey. Antony Flew (1923-2010) attacked religious belief on the grounds of the "falsification argument" (Flew et al. 1964), was subject to many rebuttals and turned to a form of deism at an advanced age. Richard Dawkins (born 1941) famously attacked religion on the basis of its contrast with science (for example: Dawkins 2006). Kai Nielsen based his atheism on skepticism and naturalism (1995, 2001, 2005 and more) and was engaged in a deep debate with D.Z. Phillips and his Wittgensteinian fideism (see further below in this chapter; Nielsen and Phillips 2005; analysis in Carroll 2010). Indeed, continuing corroborations of reasons for disbelief, as well as responses by proponents of belief, are still enthusiastically discussed to this day (Peterson and VanArragon 2007; Taliaferro et al. 2010, Part VI). All these discussions of atheism are clearly part of a WRS discourse.

In my opinion, the complete, consistent adoption of WRS does indeed lead to atheism. No attempt to prove the existence of God using the sources of this system has ever succeeded. From the viewpoint of this system, when Napoleon asked Laplace what place God had in the cosmic system he described in his book, and Laplace replied, "Sir, I have no need of that hypothesis", Laplace was correct.

\section{The adoption of religion and the rejection of reason}

The polar opposite of this approach is the rejection of the basic cognitive tools and the exclusive adoption of a model based on other, non-rational sources. However, such a polar opposite has never existed and probably will never exist. Everyone, including the staunchest anti-rationalist, needs senses to perceive the world, memory to preserve the data he has perceived and reason to analyze those data. He needs those capacities even to understand the non-rational sources he had adopted as testimonies and to read the irrationalist texts in which he believes. The religious system is therefore a system that embraces the rational system together with non-rational sources, usually texts, and their authoritative interpreters. I will now try to schematize this symbolically.

Let us call the non-rational model (or sub-model) $\mathrm{m} 7$.

$\mathrm{m} 7:(\forall \mathrm{x}, \mathrm{y} \ldots \alpha, \beta \ldots((\mathrm{x} 1, \mathrm{x} 2, \mathrm{x} 3 \ldots \in \mathrm{A}) \wedge(\alpha, \beta \ldots \in \mathrm{H})) \leftrightarrow((\mathrm{m} 8(\alpha, \beta \ldots): \varphi \rightarrow \varphi) \wedge$

$((\mathrm{m} 8: \mathrm{x} 1:(\alpha, \beta \ldots): \varphi \rightarrow \varphi) \wedge(\mathrm{m} 8: \mathrm{x} 1: \mathrm{x} 2:(\alpha, \beta \ldots): \varphi \rightarrow \varphi) \wedge(\mathrm{m} 8: \mathrm{x} 1: \mathrm{x} 2: \mathrm{x} 3 \ldots))))$ 
where A denotes the set of authoritative interpreters of the holy texts and $\mathrm{H}$ denotes the set of those holy texts themselves. To be sure, we need the basic cognitive tools to understand of the words of the authoritative interpreters, but in $\mathrm{m} 7$ these tools do not serve any role other than that of transmitting the words of the holy texts and their interpreters. The members of $\mathrm{H}$ differ from one monotheist religion to the other, and so we can speak about h1, h2, and h3, which are the bases of the models $\mathrm{m} 7.1, \mathrm{~m} 7.2$, and $\mathrm{m} 7.3$. respectively. These differences, however, do not change the basic structure of $\mathrm{m} 7$, which we call MRS in general.

$\mathrm{m} 7$ refers only to the model of the non-rational sources of MRS, but these do not exhaust the full model of its real system. This latter model consists of both $\mathrm{m} 7$ and $\mathrm{m} 8$; namely, it may adopt the basic cognitive tools for purposes other than understanding the holy texts and their authoritative interpreters. That model, which we may call $\mathrm{m} 9$, will therefore be defined as follows:

$$
\mathrm{m} 9::(\mathrm{m} 7, \mathrm{~m} 8)
$$

where the division of labor between $\mathrm{m} 7$ and $\mathrm{m} 8$ is not specified. In principle, the comma in the formula serves us only when that specification is not important, while in the case of $\mathrm{m} 7$ and $\mathrm{m} 8$ it would be very important to specify the division of labor among the different sources. The problem is that there is not one single model in any of the three traditions, and this issue was subject to fierce debates within each of them. In this case, therefore, we will leave the definition of the model with commas instead of elaborating their division of labor not because the elaboration is not important (as is the case in most of the instances in which we use commas) but because it simply does not exist, not even on the ideal level. Thus we may ask whether different schools or thinkers are actually parts of the same tradition if they do not have even an ideal system in common. The answer must be yes. Although they do not share the same division of labor among the sources, they do share the same sources.

Even though the basic cognitive tools are part and parcel of MRS, there still are eminent anti-rationalist schools and thinkers within this system. These are often referred to as fideists (for the history of the doctrine and the uses of the term see Carroll 2008). As we noted, the fideist thinkers do not and cannot reject the basic cognitive tools altogether, but they do subordinate them completely to the holy texts. These schools generally call the systems constructed out of the basic cognitive tools "reason", "understanding", "investigation", or "philosophy".

Among the Church Fathers the best-known representative of this antirationalist approach is Tertullian, but in fact the famous saying attributed to him - "Credo quia absurdum est" - was never really written by him. However, the fideist stance was well represented in later generations by quite a few important thinkers. 
In Islamic theology Taqi Ad-Din Ahmed Ibn Taymiyyah (1263-1328) is known as a staunch representative of anti-philosophical (and anti-mystical) orthodoxy. To be sure, he is not one of the most radical fideists, but he is undoubtedly one of the most influential. Ibn Taymiyyah distinguished among the various areas of rational thought. While he acknowledged its credibility in secular fields, in which the religious sources have no claim, he adamantly preached rejecting in favor of any data transmitted by the Qur'an and its authoritative interpreters. Thus, while criticizing the Sufi (mystical) and illuminationist schools, who preached suppressing one's rational faculties to achieve a mystical experience, he equally criticized the rationalist schools, especially the Mu'atazila, who subordinated the revelation to reason:

Many theologians base their idea simply on reason, and rely exclusively on it. ... Knowledge is derived from general principles of reason, sufficient in themselves without a resource to faith on the Qur'an.

Most Sufis, on the other hand, condemn reason and find fault with it. They assert that sublime states and higher spiritual stages are never attained without negating reason. They expound ideas which contradict reason and lead to rapture, ecstasy and intoxication. They believe in truths and experiences which, as they claim, accrue only when reason is completely suppressed; they also believe in things that are clearly denied by reason or are not attested by it.

Both these sources are wrong. To be sure, reason is prerequisite to all knowledge, as it is the prerequisite of virtue and good life. With it we acquire knowledge and virtue, but it is not sufficient by itself. It is only a faculty of the soul, a power like the power of vision in the eye. It works only when it receives light from faith and the Qur'an, as the eye sees only when it receives light from the sun or a fire.

Left to itself, reason cannot know things which it is not equipped to know by itself. On the other hand, when it is completely suppressed, the ideas that one receives and the acts that one performs may be things such as happen to the animals. One may have love and ecstasy and other experiences, but they will not be different from what the animals get. Hence the states that one attains by negating reason are defective, and the ideas that one receives contrary to reason are false.

Prophets came with knowledge which reason could not attain in and of itself; never did they come with what reason considers to be impossible. People who place unjustified faith in reason make statements regarding the necessity, possibility or impossibility of things purely on the basis of reason; they work all the while under the impression that their views are correct, whereas they are false; they are even audacious enough to oppose the views which the prophets taught. On the other hand, those who decry reason and affirm things that are false, revel in 
satanic states and evil practices, and cross the boundaries which the sense of discrimination (between good and evil) draws, with which God has endowed man and elevated him above other creatures (Ibn Taymiyyah 2000: 5-6).

He further states:

Knowledge is what is demonstrable, and of that what is useful has been conveyed by the prophets. However, there is a part of knowledge which we get from other sources. This concerns the matters of the world, such as the objects of medicine, mathematics, agriculture and commerce. But so far as divine things and religious truths are concerned, the only source of their knowledge is the Prophet. He knows them best, is most eager to preach them to the masses and most competent to formulate and expound them. He is above everyone in knowledge, will and competence - things which are required to accomplish his mission perfectly (ibid.: 16).

In terms of Source Theory, Ibn Taymiyyah's model is based on compartmentalization. If $\mathrm{P}$ denotes all the data pertaining to religious matters, we can describe his model as $\mathrm{m} 9.1$, according to the following formula:

$$
\mathrm{m} 9.1: \forall \varphi((\mathrm{m} 7: \varphi \rightarrow \varphi) \wedge((\psi \notin \mathrm{P}) \leftrightarrow(\mathrm{m} 8: \psi \rightarrow \psi)))
$$

A similar position, though less sharply phrased, is taken by AlGhazali, who is usually considered as a more mainstream thinker than Ibn Taymiyyah (AlGhazali 1980:63-64; idem 2000, Introduction). This seems to be the position of other Asharite thinkers as well.

Similar ideas appear, though quite sparsely, in medieval Jewish thought. The sharpest representative of the fideist approach was apparently R. Joseph Yabetz (? - c.1505), who has become particularly influential in Orthodox Judaism in modern times:

[It should be] explained that we have been commanded not to follow logical deductions. You must know, my son, that just as we have been commanded not to follow our desires, because it is an important principle in performing God's commandments, so we have been commanded not to follow the deductions made by our reason. For just as the nature of our desires is to love to do sins and despise observing prohibitions ... , so it is the nature of human reason to mislead people to love the intelligibles that they can apprehend, and despise the true opinions of the Torah, such as the belief in reward and punishment, the divine provenance of the Torah, the resurrection of the dead and the great Day of 
Judgment, which are all opposed to rational deduction. Therefore people must become accustomed to remember the commandments, which are the Divine intelligibles, so as to be saved from human reason which lies in wait for people at every time (Yabetz 1554, Chapter 8).

In the Catholic Church, the marked influence of Thomas Aquinas usually led to a rejection of fideism (also, recently, see John Paul II 1998, esp. article 53). It is in the early Protestant Church that we encounter the most flamboyant antirationalist statements. Luther's famous words against reason, even if they do not represent the more complex stance that scholars find in his entire work, are good examples of this. I will quote from his last sermon in Wittenberg (1546):

[Reason] is the foremost whore the devil has; the other gross sins can be seen, but nobody can control reason. ... [R] eason mocks and affronts God in spiritual things and has in it more hideous harlotry than any harlot. ... As a young man must resist lust and an old man avarice, so reason is by nature a harmful whore, ... Therefore, see to it that you hold reason in check and do not follow her beautiful cogitations. Throw dirt in her face and make her ugly. ... Reason is and should be drowned in baptism, and this foolish wisdom will not harm you, if you hear the beloved son of God saying, "Take, eat; this is my body, which is given for you; this bread which is administered to you, I say, is my body”, If you hear and accept this, then I trample reason and its wisdom under foot and say, "You cursed whore, shut up! Are you trying to seduce me into committing fornication with the devil?" That's the way reason is purged and made free through the Word of the Son of God (Luther 1959, Volume 51: 374-377).

Luther sees people's attraction to reason as a result of their pride and self-satisfaction:

When whoredom invades you, strike it dead, but do this far more when spiritual whoredom tempts you. Nothing pleases a man so much as self-love, when he has a passion for his own wisdom. The cupidity of a greedy man is nothing compared with a man's hearty pleasure in his own ideas, ...

Therefore I exhort you, says Paul, by the grace God has given me, not to think of yourselves more highly than you ought to think [cf. Rom $12: 3]$. What he is saying is: You still have your own proud ideas, as well as other gross sins; therefore take heed of yourselves. Hitherto you have heard the real, true Word, now beware of your own thoughts and your own wisdom. The devil will kindle the light of reason and rob you of your faith (ibid.: 377). 
And again elsewhere:

Reason is the Devil's greatest whore; by nature and manner of being she is a noxious whore; she is a prostitute, the Devil's appointed whore; whore eaten by scab and leprosy who ought to be trodden under foot and destroyed, she and her wisdom ... Throw dung in her face to make her ugly. She is and she ought to be drowned in baptism... She would deserve, the wretch, to be banished to the filthiest place in the house, to the closets (Luther 1959/73, Volume 16: 142-148).

Luther believed that reason is nothing but a tool for man's evil inclinations and corrupt morals, and thus he saw it as the messenger of Satan. In his commentary on Paul's Epistle to the Galateans he states:

[W]e, excluding all works, do go to the very head of this beast, which is called Reason, which is the fountain and headspring of all mischiefs. For reason feareth not God, it loveth not God, it trusteth not in God, but proudly condemneth him. It is not moved either with his threatenings or his promises. It is not delighted with his words or works, but it murmureth against him, it is angry with him, judgeth and hateth him: to be short, 'it is an enemy to God' Rom. 8 [:7], not giving him his glory. This pestilent beast (reason I say) being once slain, all outward and gross sins should be nothing.

Wherefore we must first and before all things go about by faith, to kill infidelity, the contempt and hating of God, murmuring against his judgment, his wrath and all his words and works; for then do we kill reason, which can be killed by none other means but faith, which in believing in God giveth unto him his glory, notwithstanding that he speaketh those things which seem both foolish, absurd and impossible to reason (Luther 1833: 172-173).

But even in the Catholic Church we find expressions of fideism. The most famous version is the ideal of sacrificium intellectus, sharply presented by the great persecutor of the Protestants, Ignatius Loyola. In his 1553 letter to the Jesuits of Portugal he first preaches to sacrifice one's will, and then turns to the sacrifice of the "understanding". This, Loyola states, is the utmost expression of obedience to God:

$[\mathrm{H}]$ e who aims at making an entire and perfect oblation of himself, in addition to his will, must offer his understanding, which is a further and the highest degree of obedience. He must not only will, but he must think the same as the superior, submitting his own judgment to that of the superior, so far as a devout will can bend the understanding. 
For although this faculty has not the freedom of the will, and naturally gives its assent to what is presented to it as true, there are, however, many instances where the evidence of the known truth is not coercive and it can, with the help of the will, favor one side or the other. When this happens every truly obedient man should conform his thought to the thought of the superior.

And this is certain, since obedience is a holocaust in which the whole man without the slightest reserve is offered in the fire of charity to his Creator and Lord through the hands of His ministers. And since it is a complete surrender of himself by which a man dispossesses himself to be possessed and governed by Divine Providence through his superiors, it cannot be held that obedience consists merely in the execution, by carrying the command into effect and in the will's acquiescence, but also in the judgment, which must approve the superior's command, insofar, as has been said, as it can, through the energy of the will bring itself to this.

Would to God that this obedience of the understanding were as much understood and practiced as it is necessary to anyone living in religion, and acceptable to God our Lord. I say necessary, for as in the celestial bodies, if the lower is to receive movement and influence from the higher it must be subject and subordinate, the one body being ordered and adjusted to the other, so when one rational creature is moved by another, as takes place in obedience, the one that is moved must be subject and subordinated to the one by which he is moved, if he is to receive influence and energy from him. And, this subjection and subordination cannot be had unless the understanding and the will of the inferior is in conformity with that of the superior.

Now, if we regard the end of obedience, as our will so our understanding may be mistaken as to what is good for us. Therefore, we think it expedient to conform our will with that of the superior to keep it from going astray, so also the understanding ought to be conformed with his to keep it from going astray. ...

$[\mathrm{H}]$ ow perfect it is in itself, and how pleasing to God, can be seen from the value of this most noble offering which is made of the most worthy part of man; in this way the obedient man becomes a living holocaust most pleasing to His Divine Majesty, keeping nothing whatever to himself, and also because of the difficulty overcome for love of Him in going against the natural inclination which all men have of following their own judgment. It follows that obedience, though it is a perfection proper to the will (which it makes ready to fulfill the will of the superior), yet, it must also, as has been said, extend to the understanding, inclining it to agree with the thought of the superior, for it is thus that we proceed with the full strength of the soul-of will and understanding - to a prompt and perfect execution (Loyola 1959: 290-293). 
One of the famous rabbis of the eighteenth century, R. Eliyahu ben Shlomo Zalman, known as the Gaon of Vilna (HaGra; 1720-1797), expressed opinions that may remind us of Ibn Taymiyyah. He too supported the study of sciences, but mainly in order to help us understand the Torah. On the other hand, he abhorred philosophy, mainly for because it presumed to discuss metaphysical questions. The only source of true data, he believed, is the Torah. And its written text of itself can provide answers to all possible questions:

The principle is that whatever has been, is now and will be forever and ever is all included in the Torah, from "In the beginning" (Genesis 1:1) to "before all Israel" (Deuteronomy 34:10). And not only the general concepts [are there], but even the details of every species and every person in particular, and everything that has happened to him from the day he was born until his end, and all his reincarnations (gilgulim) and all his subtlest details, as well as those of every ... creature in the world and every plant and inanimate substance, and all their details ... And also, all that was said of our forefathers and Moses and Israel reappears in every generation, since their [Holy] Sparks [i.e. souls] are reincarnated in every generation, as is well-known. And all their actions from Adam to the end of the Torah exist in every generation, as is known to those who understand (HaGra 1820, Chapter 5).

The Torah text is apparently autarchic, and can serve as an exclusive source. It is clear, however, that this does not refer to the overt meaning of the text but rather its "inner" notions, which must be deciphered through proper interpretation. Here too, then, the text itself cannot serve as the sole source, as intermediary sources are required to access it.

Another Jewish thinker, R. Nahman of Breslav (1772-1810), belonged to the hasidic movement, which the Gaon harshly opposed, but he embraced a similar anti-rationalism. He claimed that one should not rely on the basic cognitive tools because people are not capable of freeing themselves of the unfavorable influences of the unwanted sources - "desire and emotion". The Jewish tradition, in contrast, has been transmitted by people who raised themselves above these limitations:

[In contrast to what some philosophers suggested], there are no biblical verses that teach us to know God through human speculation built on confused sophistry. Heaven forbid! The only way to know God is in the way taught by our holy forefathers, who struggled all their lives for Him. They divested themselves of all worldly matters, totally subjugating all desire and emotion. Above all, they achieved total mastery of their sexual drives, releasing themselves from the bondage of the universal root of evil. They were consequently able to perfect their intellect and truly 
recognize their Creator. This is the heritage they bequeathed us. It is our duty to accept this heritage with joy. Thus we say in our prayers: "Happy are we! How good is our portion! How pleasant is our lot! How beautiful is our heritage!" - The main lesson of these verses is that we take this holy knowledge into our minds, bring it into our hearts and bind it there constantly, "that His fear be on our faces that we sin not" (R. Nahman of Breslav 1973: 217).

The intended conclusion is that one should adopt the sacred texts as one's sole source. The source of these texts is God, but the intermediary sources are the holy individuals (Tzadikim) who transmitted the word of God to the people over the centuries:

You must carefully remove all speculation from your heart. Cast it away and do not think about it at all. All you need is pure faith in God and in the true Tzadikim. [For w] e have received the Torah through Moses our Teacher, and it has been transmitted to us by the awesome Tzadikim of each generation. There is no question as to their integrity and they can be relied upon without question. All one must do is follow in their footsteps, believing in God with innocent simplicity and keep the commandments of the Torah as taught by our holy ancestors (ibid.: 32).

Kierkegaard (1813-1855) typically presents the "ridiculous" - i.e., irrational character of religious belief and sees it as the believer's main test:

The antinomy must now be resolved: that one shall believe that which derision can render ridiculous, which one can see done in a secular and earthly way. This is an even higher accentuation than credo quia absurdum. To the simple man it simply says: All you have to do is believe. To the comprehending understanding it says: It is diametrically opposed to the understanding, but you shall believe. Here the shall is stronger just because it is in opposition to something. In relation to the most caustic mockery of intellectuality it says: Well now, seen from your point of view it is ridiculous, extremely ridiculous, the most ridiculous of all but you shall believe; it is a matter of heaven or hell, you shall. This is a frightful shall precisely because it makes such a great concession to the opposition.

I now understand better and better the original and profound relationship I have to the comic, and this will be useful to me in illuminating Christianity.

For this reason it is appropriate for my own fragment of life to express this dialectic: that I have allowed myself to be laughed at - but what I say is true. 
When no concession at all is made to the opposition, then the shall related to it is not nearly so strong. The greater the concession, the more frightful this shall. The concession is, so to speak, the height of the shower bath.

Therefore the one who is to present Christianity must eminently have what the most caustic scoffer has at his disposal - precisely in order to pose this: shall (Kierkegaard 1967-78, VI, article 6373:133).

But even he, the great paragon of fideism in the modern era, does not reject the "understanding" altogether. He continues:

[T] he believing Christian both has and uses his understanding, respects the universally human, does not explain someone's not becoming a Christian as a lack of understanding, but believes Christianity against the understanding and here uses the understanding -in order to see to it that he believes against the understanding. Therefore he cannot believe nonsense against the understanding, which one might fear, because the understanding will penetratingly perceive that it is nonsense and hinder him in believing it, but he uses the understanding so much that through it he becomes aware of the incomprehensible, and now, believing, he relates himself to it against the understanding (Kierkegaard 1982, I: 568).

Fideistic approaches also exist among contemporary thinkers. Fideism is often attributed to the theology of Karl Barth (1886-1968), and, following Wittgenstein's later philosophy, a philosophical stream of "Wittgensteinian fideism" has emerged recently (Nielsen and Phillips 2005; Carroll 2010). Philosophers such as Norman Malcolm (1911-1990), Dewi Z. Phillips (1934-2006) and Peter Winch (1926-1997) consider religion as a "language game" of its own, different from that of science and other reason-based fields. As a result, they contend that religion is not expected to comply with science, nor should religion be confronted with science (See: Malcolm 1995; Phillips 1976, 1986, 1993; Winch 1995). Even if these thinkers are inclined to the currently fashionable reliance on linguistic rather than epistemological models, their theories in fact have epistemological meaning and fit well into the formula presented above. (This book does not reduce aspects of epistemology to language, but rather reduces some aspects of language to epistemology, as we shall see below in Chapter Seven.)

Each of the thinkers presented in this section is saying that only one system, namely his own, should be adopted, and that its rival should be rejected. The same is true for the radical secular approach presented in the previous section. In spite of the apparent symmetry between the two exclusivist approaches, there is a difference as well. The radical secular approach absolutely rejects the religious sources, while the radical religious (fideist) approach - even though it sometimes seems to completely reject "reason" and "investigation" on the 
declarative level - actually means that these should be rejected only on issues that are liable to clash with the data of the religious tradition, since it is unlikely that even anti-rationalist religious thinkers would insist that the basic cognitive tools should not be used for everyday issues. Moreover, they too accept the fact that in order to understand the data transmitted to us by the holy texts, we need to use our basic cognitive tools. Thus it would seem that there is no system that completely rejects the basic cognitive tools. We can therefore say that the symmetry between the approaches is not total, since the radical secular approach does not consider religion to be a source at all, while the radical religious approach considers the basic cognitive tools to be sources subordinate to the supreme source, which is the holy text. It seems that this is the case for most of the systems whose models apparently reject the basic cognitive tools. Nevertheless, we can say that once the fideist MRS model is established and the basic cognitive tools are given their (humble) place in it, they become part and parcel of it, and from now on there is a symmetry: Each of the exclusivist approaches vocally rejects the rival one. The issue becomes more complex among the religious thinkers who make an attempt to adopt the basic sources of both systems.

\section{The double-faith theory}

The medieval religious rationalist tradition is dominated by the double-faith theory. This theory claims that there are two parallel roads to religious belief through the religious tradition and through "Reason" (that is, the basic cognitive tools) - and that both lead to the same data. This basic idea is expressed by Saadia Gaon, Ibn Rushd (Averroes), Thomas Aquinas, and many other thinkers.

This claim is obviously a dogmatic one. Clearly, even the promulgators of this theory were well aware that the data of MRS and WRS are sometimes contradictory, but they thought that such contradictions stem from the improper operation of one of the two systems and that it is necessary to put in the effort to resolve the contradictions. This implies that in cases of this sort, the proponents of this approach think that the contradiction is merely an apparent one and that the data of either WRS or MRS must be reinterpreted so as to eliminate it. However, these two potential ways of resolving the contradiction are very different. One method is to consider the data of MRS superior and try to interpret the data of WRS accordingly, while the other is to do exactly the opposite. The first method can be formulated as follows:

M10.1: $((\mathrm{m} 7: \varphi \rightarrow(\varphi \wedge \mathrm{m} 8: \varphi))$

while the other can be formulated as follows:

M10.2: $((\mathrm{m} 8: \varphi \rightarrow(\varphi \wedge \mathrm{m} 7: \varphi))$ 
The first method (m10.1) is represented by Saadia Gaon (c.882-942), Ibn Rushd (Averroes; 1126-1198) and Thomas Aquinas (1225-1274). In Saadia's opinion, if people come to have doubts about their religious faith due to rationalist inquiry, they must have fallen into one of seven fallacies in the rationalist method of thinking:

Should, therefore, someone come to us with an allegation in the realm of inferential knowledge, we would test his thesis by means of these seven criteria. If, upon being rubbed by their touchstone and weighed by their balance, it turns out to be correct as well as acceptable, we shall make use of it. Similarly also must we proceed with the subject matters of authentic tradition - I mean the books of prophecy (Saadia 1948, Introductory Treatise, Section v: 26).

God is the one who implanted the capacity of rational thinking within us, and therefore it cannot contradict His Word. According to Saadia, God assures the believer:

There is no wise or distinguished man that I do not know. Hence it is impossible that he should be able to produce an argument against you in the matter of your religion or do injury to your creed, because my knowledge is all-embracing and I have imparted it to you (ibid., Section vi: $30-31)$.

A similar view is presented by Ibn Rushd. He claims, however, that there is a religious obligation to attain the shared truth through reason as well, and that the data transmitted by the Qur'an are not sufficient:

We maintain that the business of philosophy is nothing other than to look into creation and to ponder over it in order to be guided to the Creator - in other words, to look into the meaning of existence. For the knowledge of creation leads to the cognizance of the Creator, through the knowledge of the created. The more perfect becomes the knowledge of creation, the more perfect becomes the knowledge of the Creator. The Law encourages and exhorts us to observe creation. Thus, it is clear that this is to be taken either as a religious injunction or as something approved by the Law. But the Law urges us to observe creation by means of reason and demands the knowledge thereof through reason. This is evident from different verses of the Qur'an. For example, the Qur'an says: "Wherefore take example from them, you who have eyes" [Qur'an 49.2]. That is a clear indication of the necessity of using the reasoning faculty, or rather both reason and religion, in the interpretation of things (Ibn Rushd 1961: 1) 
Thomas Aquinas expresses a similar opinion in his introduction to Summa Theologica. First he states that human reason does not exhaust all the truth and therefore divine revelation is needed. However, he insists, it would be better if that truth could be obtained from another source:

Sciences are differentiated according to the various means through which knowledge is obtained. For the astronomer and the physicist both may prove the same conclusion: that the earth, for instance, is round: the astronomer by means of mathematics (i.e. abstracting from matter), but the physicist by means of matter itself. Hence there is no reason why those things which may be learned from philosophical science, so far as they can be known by natural reason, may not also be taught us by another science so far as they fall within revelation. Hence theology included in sacred doctrine differs in kind from that theology which is part of philosophy (Aquinas1920, Introduction).

If human understanding can grasp metaphysical truth by its own power, why was it given to us in the sacred writings? According to these three thinkers, metaphysical truth was transmitted in the sacred writings in laymen's terms, so that even the masses who are not capable of grasping the truth with their intellect could at least obtain it in a simple form, but a complete understanding of this truth through reason would be preferable.

These three religious rationalists thus claim that the two systems cannot lead to a contradiction, and if this seems to occur, then the only explanation is that the individual using WRS has failed in one of methods of using the system. This implies that in such a case he must reconsider the matter until he reaches the right conclusion - that of MRS - and if he cannot do so, then he must subordinate his own opinion to "authentic tradition - ... [namely], the books of prophecy" (in the words of Saadia Gaon). Aquinas too claims that the "sacred doctrine" is a type of science, based on reason, but subordinate to the "principles" transmitted by the sacred writings:

Sacred doctrine is a science. We must bear in mind that there are two kinds of sciences. There are some which proceed from a principle known by the natural light of intelligence, such as arithmetic and geometry and the like. There are some which proceed from principles known by the light of a higher science: thus the science of perspective proceeds from principles established by geometry, and music from principles established by arithmetic. So it is that sacred doctrine is a science because it proceeds from principles established by the light of a higher science, namely, the science of God and the blessed. Hence, just as the musician accepts on authority the principles taught him by the mathematician, so sacred science is established on principles revealed by God ... The 
principles of any science are either in themselves self-evident, or reducible to the conclusions of a higher science; and such, as we have said, are the principles of sacred doctrine (ibid).

In terms of Source Theory, these three thinkers are trying to construct a combined system out of two different systems - WRS and MRS - by establishing a clear hierarchy in which MRS is superior and WRS is subordinate to it. This subordination is supposed to be achieved by re-interpretation of the philosophical (that is, rational) truths in a way that will make them comply with the "principles" of the sacred writings. Indeed, in practice all three thinkers are not always faithful to this method, and in many cases they re-interpret the religious texts so that they fit the data of WRS, but their declared method is the one that allegedly gives supremacy to MRS.

The opposite method, which subordinates MRS to WRS, is represented by Maimonides, at least in one of his famous arguments. When he discusses the idea that God is not material and is not a power within the material, he devotes the whole first part of his Guide of the Perplexed to a re-interpretation of the Biblical verses which present anthropomorphical formulations. When he discusses the issue of whether the world is created or eternal, he comes to the conclusion that this is an antinomy for the basic cognitive tools (which he calls "demonstration") - that is, it is possible to argue that the world is eternal as persuasively as to argue that it is created. He therefore claims that the latter view should be accepted because it is the one that is found in the Biblical text. He adds, however:

Know that our shunning the affirmation of the eternity of the world is not due to a text figuring in the Torah according to which the world has been produced in time. For the texts indicating that the world has been produced in time are not more numerous than those indicating that the deity is a body. Nor are the gates of figurative interpretation shut in our faces or impossible of access to us regarding the subject of the creation of the world in time. For we could interpret them as figurative, as we have done when denying His corporeality. Perhaps this would even be much easier to do: we should be very well able to give a figurative interpretation of those texts and to affirm as true the eternity of the world, just as we have given a figurative interpretation of those other texts and have denied that He, may He be exalted, is a body.

Two causes are responsible for our not doing this or believing it. One of them is as follows. That the deity is not a body has been demonstrated; from this it follows necessarily that everything that in its external [=literal] meaning disagrees with this demonstration must be interpreted figuratively, for it is known that such texts are of necessity fit for figurative interpretation. However, the eternity of the world has not been 
demonstrated. Consequently in this case the texts ought not be rejected and figuratively interpreted in order to make prevail an opinion whose contrary can be made to prevail by means of various sorts of arguments. This is one cause.

The second cause is as follows. Our belief that the deity is not a body destroys for us none of the foundations of the Law and does not give the lie to the claims of any prophet. The only objection to it is constituted by the fact that the ignorant think that this belief is contrary to the text; yet it is not contrary to it, as we have explained, but is intended by the text. On the other hand, the belief in eternity the way Aristotle sees it - that is, the belief according to which the world exists in virtue of necessity, that no nature changes at all, and that the customary course of events cannot be modified with regard to anything - destroys the Law in its principle, necessarily gives the lie to every miracle, and reduces to inanity all the hopes and threats that the Law has held out, unless by God! - one interprets the miracles figuratively also, as was done by Islamic internalists; this, however, would result in some sort of crazy imaginings.

If, however, one believed the eternity according to the second opinion we have explained - which is the opinion of Plato - according to which the heavens too are subject to generation and corruption, this opinion would not destroy the foundations of the Law and would be followed not by the lie being given to the miracles, but by their becoming admissible. It would also be possible to interpret figuratively the texts in accordance with this opinion. And many obscure passages can be found in the texts of the Torah and others with which this opinion could be connected or rather by means of which it could be proved. However, no necessity could impel us to do this unless this opinion were demonstrated. In view of the fact that it has not been demonstrated, we shall not favor this opinion, nor shall we at all heed that other opinion, but rather shall take the texts according to their external sense and shall say: The Law has given us knowledge of a matter the grasp of which is not within our power, and the miracle attests to the correctness of our claims (Maimonides 1963, II, Chapter 25: 327-329).

In this case Maimonides does indeed give priority to the data of MRS, but only because WRS did not provide enough clear, unambiguous data. Here too the important thing is his general credo, which states that whenever WRS provides us with clear, unambiguous data we have to accept them and reinterpret the religious sources accordingly. Thus Maimonides has also created a combined hierarchical system, except that in his case the WRS sources have priority and the MRS sources are subordinate to them. He himself indicates an example of his use of this method - his willingness to reinterpret the Biblical verses whose 
surface meaning is that God has a body, so as to accord with rationalist philosophy, which claims that He does not.

Incidentally, Maimonides's method, involving a change in the concept of the Deity, is also a good example of what I discussed in Chapter Four above, about changing the boundaries of a concept. At first glance it would seem appropriate to ask whether Maimonides's God is actually the Biblical God. Doesn't the change in the concept of God lead to a situation in which the two texts the Bible and Maimonides - are actually talking about different objects? The answer to this is not unequivocal. Let's take it as a premise that the author of the Biblical text meant the literal ("external") sense of its words, as understood by the common people. Now, if Maimonides and the common people shared the same system, we could say that Maimonides had taken an accepted datum from his cultural community and attempted to change it out of a new understanding drawn from the sources of that system. But since Maimonides actually tried to subordinate this system to another one, which is not shared by the common people, it is very likely that he was trying to introduce a new term in place of the old one, taking advantage of the old term's prestige within the cultural community (in the way that Spinoza's use of the word "God" should be understood). However, the fact that Maimonides seems to truly and sincerely consider his concept of "God" to be the same one that is transmitted by the Bible shows that he considers himself as drawing from the same religious system as the community he belongs to, and is merely trying to "amend" this concept from within, as it were.

It should be added, that the basic idea of the "double-faith" theory is shared by some of the contemporary philosophers of religion. Most notable is Alvin Plantinga (born 1934), whose theory attempts to meet the challenges of evidentialist criticism and prove that religion is rational (Plantinga 2006 and other works). William Alston (1921-2009) contended that religious experience is not significantly different from sensual perception, and therefore should be admitted as one of the sources of WRS (Alston 1991). Theories of "religious epistemology" suggest that we can offer rational justification to religious truths if we only recognize that slightly different rational standards than the ones that apply to philosophical and scientific knowledge should apply to religious knowledge. One of the most intriguing theories in this field, and one that speaks in a language quite close to Source Theory, is Zagzebski's theory of "epistemic authority" (Zagzebski 2013). Zagzebski claims that there are moral as well as epistemic good reasons to trust not only our own capacities, but also that of others. This, she continues, may give epistemic justification to religious beliefs. We can easily identify Zagzebsi's concept of "trust" as a form of "source adoption", in our terminology. If so, in Zagzabski's theory the religious sources are not adopted as superior sources but only authorized by virtue of arguments in WRS, and thus adopted only as subordinate sources of that system. Thus, MRS becomes a subsystem within WRS. In this way a full compatibility 
between the two is achieved (at least in principle), in the spirit of the "doublefaith" theory.

\section{The separationist approach}

This is actually a family of approaches, which claim that the sources of one system should be adopted for some particular purposes and the sources of another system for other purposes. In terms of Source Theory, these approaches suggest compartmentalizing mechanisms. There can clearly be many different ways of compartmentalizing, but for our purposes we will concentrate on the approaches that separate descriptive data (called "beliefs" in MRS) from normative data (called "commandments" in this system). I will call this family of approaches "separationist" (following Rosenberg 1988), but two the specific forms I will discuss here, both relating to the Jewish context, is the one known as "orthopraxy" and the one I will call "Orthopistism".

"Orthopraxy" is the name often used to describe the approach that attempts to draw only normative data from MRS and disregard it descriptive data. If $\mathrm{N}$ denotes the set of normative data, this approach can be formalized as follows:

$$
\text { m11.1: }(((\varphi \in \mathrm{N}) \leftrightarrow(\mathrm{m} 7: \varphi \rightarrow \varphi)) \wedge((\varphi \notin \mathrm{N}) \leftrightarrow(\mathrm{m} 8: \varphi \rightarrow \varphi)))
$$

or, in short:

$$
\mathrm{m} 11.1::((\in \mathrm{N} / \mathrm{m} 7),(\notin \mathrm{N} / \mathrm{m} 8))
$$

The most radical proponent of this approach in modern Jewish thought is Yeshayahu Leibowitz (1903-1994). He claims that any attempt to draw descriptive data from the Bible is an attempt to make use of it to satisfy human needs. He considers this an inferior religious commitment. In contrast, his religious ideal is that the Bible should not serve as a means for satisfying human needs, not even the need for "scientific information", but only for religious imperatives to serve God - that is, the practical commandments. He puts it this way:

Does religion provide information? This was considered obvious in the Middle Ages, when thinkers did not distinguish between information and meaning. The meaning they attributed to reality was embodied in the information they had, or thought they had, about the world. ... But now we draw information without any meaning from science, and we are not obligated to attribute any informative content to religious thought.

We have a source of information, which is science, and from a psychological standpoint the information it provides imposes itself on the mind of anyone who understands it, since no one is capable of not knowing what he knows. The basic, determining factor of religious feeling and 
awareness is not the information that can, or cannot, be extracted from religion; rather, it is the fact that the essence of religion is a demand presented to the individual: to worship God. This aspect of religious belief has, of course, always been the essence of Judaism, although nowadays it is likely to be more salient than it was in the Middle Ages, when people attributed informative meaning to religion as well.

If we derive our information from science, which is independent of beliefs and values, then the world of people with the awareness that they are standing before God is not the same world that they grasp through the information they receive; rather, their religious awareness is concentrated on the point of obedience to the demands that this stance implies: accepting the burden of the Torah and the commandments. The essence of religious belief is not the knowledge that something is a fact; it is what the religious person determines and decides (1992, Chapter 13; emphasis in original).

Thus Leibowitz sees the Bible as the source of normative, but not descriptive, data. He claims that descriptive data should be drawn from WRS, which relies on the basic cognitive tools, and especially from science, which is a subsystem of WRS. He does not, however, consider this system to be a source of normative data.

The opposite separatist approach can be called "orthopistism".. This approach sees the holy texts of MRS as sources of only descriptive statements (beliefs), while it considers the basic cognitive tools as the source of normative statements. In the Jewish context discussed here this approach can be described as non-halakhic. If $\mathrm{D}$ denotes the set of descriptive, this approach can be formalized as follows:

$\mathrm{m} 11.2:(((\varphi \in \mathrm{D}) \leftrightarrow(\mathrm{m} 7: \varphi \rightarrow \varphi)) \wedge((\varphi \notin \mathrm{D}) \leftrightarrow(\mathrm{m} 8: \varphi \rightarrow \varphi)))$

or, in short:

$\mathrm{m} 11.1::((\in \mathrm{D} / \mathrm{m} 7),(\notin \mathrm{D} / \mathrm{m} 8))$

As far as I know, no Jewish thinker has ever made such a radical statement. The closest position to this approach in the Jewish world is that of some early thinkers in the Reform movement. One of the pioneers of this movement, Saul Ascher (1767-1822), expresses this view as follows:

It seems, as will be explained later, that at first the Eternal God did not plan to give the Jewish people laws in the full sense of the word. If $\mathrm{He}$ had chained the weak powers of the nation with laws, He would have tested their tolerance too severely and caused them to sin without reason (Ascher 1792, Volume 2, Chapter1). 
In Ascher's view, the Torah is not a source of laws, but mainly of beliefs:

If we carefully consider what we have deduced and developed from the Torah, we will find proven what we proposed at first - that belief is the prior condition for any revealed religion.

We see that faith was in decline from the time of Noah until a certain generation of his descendants. The Torah describes Noah in only one way - as a person who walked in the way of God. Nature had thus granted him a stronger faith than was common among other people. This faith was the condition for the Divine revelations he received, and he never refused, even for a moment, to act according to the command of the revelation.

Second, what we have discussed so far shows that religion lies at the basis of Judaism. This means that Judaism includes a method by which a particular human society becomes accustomed to defined concepts, and all its members are required to understand these concepts the same way. The true, sublime goal of every religion is to provide people with certain truths and describe them in a way that is more understandable than they could grasp as children.

Third, we see that God chose revelation because human beings cannot understand the truths with their own understanding, without any intermediary. Revelation created more interest in these truths and caused people to adhere to them more strongly.

Fourth, at the time in Jewish history that we have been discussing, we have seen that faith was merely regulative as a condition for revelation ... All people had the same traits - they only knew one way to go. Therefore God did not need to use threats to compel the people to hold their faith. He merely gave them signs. A particular event or vision was enough to strengthen their faith. This was the case with the crossing of the Red Sea; when the Israelites saw the doomed Egyptians behind them, in the words of the Bible, "They believed in God and in Moses His servant" [Exodus 14:31].

All this makes it clear that Judaism is a revealed religion. That is, God chose Judaism as a means of teaching some people to think in a different way. This is how the concept of "revealed religion" should be understood (ibid., Chapter 2).

A first glance, it seems that Ascher is saying that the Torah is also a source of norms, but that these are not "laws" (influenced by Kant, he vehemently opposes the "statutory" character of traditional Judaism), but rather abstract values. However, a deeper look shows that these values are moral ones, which he (and his contemporaries) considered to be deduced from universal reason. Thus, in the realm of norms, Ascher is not using MRS but rather WRS. 
According to his declared compartmentalization, MRS is purely a source of beliefs, while the "commandments" are drawn from WRS.

Here we can ask if Ascher was really loyal to MRS in the realm of beliefs. If he had been faced with the more modern problems of the conflict between science and religion that came up some decades after his time, would he have adhered to the Torah as the sole source of beliefs and rejected science? It would not be prudent for me to speculate about this, but it does seem probable that in such a case Ascher would have rejected the beliefs provided by MRS in favor of those provided by the scientific subsystem of WRS, as did most Reform thinkers in the following generations, whether by rejecting the religious beliefs explicitly or by reinterpreting them according to the prevailing scientific beliefs. If so, Ascher's compartmentalization is not absolute; however, it is not the specific individual that we are focusing on here, but rather the ideal type that we can delineate through Ascher's writings.

In sum, both methods of compartmentalization - the orthopraxic and the orthopististic - represent attempts to preserve the two systems in parallel, even if they actually do both systems a disservice, since each system considers itself a total one, and such a separation cannot be justified. Even though two of the thinkers cited here tried to justify their methods within MRS, it seems to me that they used a manipulative interpretation of the system's data in a way that was dictated by the sources of another system - that is, WRS.

\section{The double-truth theory}

Finally, we will consider the double-truth theory, which was developed in medieval philosophy, but did not acquire many supporters. Siger de Brabant (c.1240-c.1284) and Boethius of Dacia (13th century) were accused of accepting it, but probably did not really embrace it. One of the very few who openly held this theory was Isaac Albalag (13th century), who was one of the most impressive Jewish thinkers of the Middle Ages (even though he has not been given much scholarly attention). In a certain sense, he developed the initial nucleus of Source Theory, which was one of the inspirations for the theory presented here, and he did this clearly and systematically. His book, The Emendation of Opinions, which was written as a commentary on Al-Ghazali's book, The Opinions of the Philosophers, deals with the two systems, MRS and WRS. He calls rationally-attained knowledge "demonstration" or "the natural way of thinking" and knowledge drawn from Scripture the "prophetic or miraculous way of thinking". As with most medieval philosophers, the main issue he discusses is whether the world is created ex nihilo or is eternal. On the philosophical, rational level, he suggests his own solution, which he calls "the perfect creation ex nihilo" - a clearly manipulative extension of the term "creation ex nihilo". This solution is that the world is contingent, and therefore depends on 
God at every moment, but in actuality it has always existed without any starting point in time. He is aware that this idea is closer to the idea of the eternity of the world than to the simple Biblical notion that the world was created at a point in time. He claims that he could reinterpret the Bible allegorically to fit his notion, and he even provides an example as a sort of intellectual exercise, but he insists that this is not the proper way to deal with the issue. Instead he presents a different way of treating the two systems, which was called, centuries later, the "double-truth theory" (as distinct from the double-faith theory discussed above). This theory states that we should hold both systems in parallel and take a non liquet approach to them. In the language of Source Theory we could formulate it as:

$\mathrm{m} 12: \mathrm{m} 8 / \mathrm{m} 9$,

which means:

$\mathrm{m} 12:(\mathrm{m} 12: \mathrm{m} 8 \vee \mathrm{m} 12: \mathrm{m} 9)$

Albalag describes this theory as follows:

One should learn truth from demonstration, and then consult the Torah. Now, if its words are in conformity with the demonstrated doctrine, we shall admit it into our belief both in virtue of demonstration and in virtue of faith. If no scriptural text can be found to support the demonstrated doctrine, we shall believe it in virtue of speculation alone. Finally, if a scriptural text is found to contradict this doctrine, we shall similarly believe the literal sense of the text in the miraculous way [of thinking], while bearing in mind that the doctrine of the scriptural text in question is alien to our [rational] knowledge only because it is one of those divine doctrines reserved for the prophets to understand, and depends on a supernatural capacity. It is in this way that you shall find my rational opinion contrary to my faith in many points, for I know by demonstration that such a thing is true by the natural way [of thinking] and I know at the same time by the words of the prophets that the contrary is true by the miraculous way [of thinking].

Moreover, even if I confirm that the demonstrable doctrine is compatible with a scriptural text, I am not certain that this is the veritable intention of the text, and not another. Therefore I do not claim to believe in the truth of the biblical exegeses that I have been able to provide here, nor to teach them as a belief that I transmit to you. Rather, I meant to show you that the speculative doctrines are reliable, and that scripture can accord with them just as much as it accords with their contrary, and perhaps even more. 
The reason I did this is that you should not be one of those who rush to deny speculative doctrines because of what seems to them at first glance to be the opinion of Scripture, since they try to corroborate this opinion by arguments that they believe to be stronger than those of the philosophers' ... and think their own arguments to be demonstrative, although they are definitely not. There are many people who follow this path in every nation, even in ours, and even our master Moses [Maimonides] is one of them. These people failed twice: once by denying the speculation and claiming that it was non-demonstrative; and secondly by claiming that their own idea was what the prophet meant. I mentioned at the beginning of the book that the our understanding cannot grasp the intentions of the Torah beyond any doubt, for just as only a philosopher can grasp the intent of [another] philosopher, so only a prophet can grasp the intent of [another] prophet. The reason [for this] is that their ways of understanding are different from one another - indeed, opposite to one another, since the latter conceives the intelligible through the senses while the former conceives the sensual through the intellect.

Undoubtedly, just as their ways of understanding are very different, so the contents of their understandings are very remote from one another, so much so that one may conceive from below the very opposite of what the other conceives from above. Therefore we should not question one from the viewpoint of the other; rather, the wise man should believe the one when his argument is based on demonstration and accept the words of the other in the way of simple faith. And even if the statements of the one contradict those of the other, one should not reject these in favor of those, for one of the virtues of religious belief is that even if it is refuted by [rational] demonstration it is not denied the possibility of being true, since what is [conceived as] impossible under the laws of nature from the standpoint of logical investigation may be affirmed as a part of the Lord's powers by prophetic understanding ... Therefore there are numerous things that are conceived as impossible by the speculative knowledge, yet are conceived as possible by Torah knowledge. Moreover, there are things that the philosopher can grasp in his investigations that cannot be grasped by the prophet through prophecy, but only insofar as he is engaged in rational investigation. And this is not because prophecy is deficient [in comparison to rational thinking], but rather because it transcends it. (Albalag 1973, Chapter 30; translation based partly on Sirat 1985: 241).

When Albalag claims that prophecy should be given priority over rational thinking, he is merely paying lip service to the concept. He actually believes that those who are not prophets, and therefore cannot clearly understand what the prophets are saying, should not give the words of the prophets any supremacy 
over the data transmitted by rational inquiry. Rather, they should continue to make use of both systems in parallel. Moreover, he insinuates that if the common people thought rationally, they would come to the same conclusions that he himself reached through the use of WRS, and then it would be clear that "their [rational] opinion is undoubtedly my opinion and the belief of the Torah is my belief, the one according to the natural way and the other according to the miraculous one. And if you understand what I am saying, then you will know that my opinion is true and my belief is true".

Albalag seems to be discussing only the descriptive data of the two systems, but he does not say this explicitly, so I will take the liberty - at least for the purposes of our theoretic discussion - of interpreting his comments as referring to all aspects of the systems - their descriptive data, their normative data, and any other data they may transmit. Under this interpretation, Albalag is presenting a method that clearly adheres to the principle of the purest utilization, which was presented above (Chapter Four) as the recommended method for people who are looking to adopt a source model. This principle stated that every person must utilize all of the systems he is capable of utilizing, and only those systems. To remind ourselves, the following secondary principles were derived from it:

The conservative rule: A person should stay with his native system unless he can no longer maintain his adoption of it.

The separation rule: A person who has two or more native systems should keep them all without trying to combine them.

The exhaustiveness rule: A person should be maximally knowledgeable about his or her native system, its basic sources, and the division of labor among them, and should try to receive the maximum amount of data that the system can provide him. The same is true in the case when a person has more than one native system.

As I deduced above, the result of this principle and the rules derived from it is that people who have a psychological attachment to two or more systems are in a permanent state of non liquet with regard to these systems.

Albalag seems to systematically hold this principle and the rules derived from it. It would seem that he was fully and deeply acquainted with both MRS and WRS, and that he had formed a psychological attachment to each of them. He felt a deep identification with each system, understanding its internal logic and self-justification, and he considered it unfair to distort either system or reject parts of it in favor of the other in an attempt to achieve a forced harmony between them. He therefore held each one separately, acting as if each one were a different computer program. He would input a question into each of the programs to see what answer it would provide on the basis of its sources. He would then compare the outputs, but would not attempt to decide between 
them, since he had no non-arbitrary way to make such a decision. He therefore chose to keep each one separately, in a state of non liquet.

Some people feel uncomfortable with this approach, considering it a form of intellectual split or compartmentalization. After all, the critics say, Albalag was a human being who was unlikely to be able to maintain absolute neutrality between the two systems. Thus, whenever their basic sources would have provided him with conflicting data, he would probably have felt a greater psychological attachment to the data of one system than to those of the other. However, on this issue Albalag, fortunately enough, was not a modern thinker. He was not interested in the existential question of whether the self identifies with "its truth", but rather with what the truth itself is. Indeed, he would have been willing to sacrifice his psychological needs and intellectual comfort for that "truth". Moreover, he would even have been willing to sacrifice his own sense of psychological integrity for the sake of preserving the integrity of the systems that aspire to provide that truth. From his standpoint, even if he felt a greater psychological closeness to the data of one system than to the contradictory data of the other, this sense of closeness is not evidence that these data are more true, but only of the subjective psychological state of the system user.

However, even if it was not Albalag's main intent, his approach paradoxically also satisfies some deep existential sentiments, maybe even deeper than the need for harmony between sources. Anyone who has become deeply acquainted with both WRS and MRS, as Albalag was, is aware of the immense cultural and intellectual forces that they contain. Anyone who fully and sincerely allows himself to absorb these forces will find it difficult to identify with radical secular messages of the sort proposed by d'Holbach and Russell or radical anti-rationalist messages of the sort proposed by Loyola, Luther, Rabbi Nahman, and the like. Anyone who is truly familiar with a religious tradition and is acquainted with modern believers can no longer say that such traditions are based solely on fear, just as anyone who is familiar with WRS can no longer say that its only purpose is to release people's "desires" and evil inclinations. The roots of the two systems are different. WRS maintains a cautious trust in the basic cognitive tools, under the assumption that these sources are after all more reliable than authorities who presume to transcend them, while MRS maintains a great deal of distrust for these cognitive tools, both in view of their limited capacity and in fear of the influence that undesired sources may exercise upon them. Rather, MRS favors the data transmitted by sources that are considered reliable, having passed the test of time, and are said to be traced back to a supernatural source, which is free of the limitations and weaknesses of human nature. Now, since the adoption of a source model is to a great extent a function of psychological attachment, the question of trust is a crucial factor in it, as every individual adopts a source model according to the trust that he has in it. However, when a person is closely acquainted with both of the systems to more or less the same 
degree, he can understand the internal logic of both of them and can develop a psychological attachment to both.

Indeed, the model presented here for the philosophy of religion, which was illustrated for two particular systems, is equally applicable to the relations between any two systems that a person becomes deeply acquainted with and with which he identifies. Source Theory makes it possible for people to live in two worlds, as it were, on the condition that they become accustomed to replacing the Kantian question "What can I know?" with the question "What can I know within each of the systems that I am able to operate?" 